\author{
Aleksander STREUBEL ${ }^{1}$ \\ Marek KURAN ${ }^{2}$ \\ Rafal SUBBOTKO ${ }^{3}$
}

\title{
PROBLEMY TECHNOLOGICZNE WYKONANIA OTWORÓW CYLINDRYCZNYCH WYNIKAJĄCE Z ICH ZASTOSOWANIA
}

\begin{abstract}
W pracy omówiono problemy z przygotowaniem cylindrycznych otworów do montażu w przedmiotach stosowanych w układach sterujących, w hydraulice siłowej oraz przeznaczonych do prowadzenia reakcji chemicznych. Niekiedy wielu problemów nastręcza wykonanie oraz montaż prostej części. Pozornie błahe powierzchnie, jak np. prostopadłe do osi otworu dno czy fazy, decyduja de facto o szczelności połączeń, a więc o poprawności pracy gotowego wyrobu. Części składowe hydrauliki siłowej należą do produktów wymagających specyficznego procesu technologicznego. Przykładowo, w procesie wytwarzania zaworu konieczne jest zastosowanie nowoczesnych rozwiązań konstrukcyjnych narzędzi, co pozwala na ograniczenie liczby braków. Przedmioty wykonywane dla przemysłu chemicznego mają do spełnienia różne zadania. Wymaga to stosowania każdorazowo indywidualnych metod obróbki, często odbiegających od powszechnie wykorzystywanych i nie każdy zakład produkcyjny jest w stanie je spełnić. Zwrócono uwagę na wymagania technologiczne, które należy spełnić, by wykonane elementy działały poprawnie i zgodnie z oczekiwaniami.
\end{abstract}

Słowa kluczowe: obróbka skrawaniem, otwory cylindryczne, współosiowość

W wielu dziedzinach gospodarki, takich jak motoryzacja, górnictwo, budownictwo zastosowanie znalazły hydrauliczne układy napędowe oraz sterujące. Newralgiczną częścią tych napędów są cylindry z tłokiem, natomiast w układach sterujących są to różnego rodzaju zawory, w szczególności zawory bezpieczeństwa zapewniające odpowiednie ciśnienie czynnika. Poprawność działania takich zaworów ma wysoki priorytet i jest testowana na specjalnie do tego przeznaczonych stacjach prób pod ciśnieniem przekraczającym wartości robocze. Ma to na celu wyeliminowanie wszelkich przecieków, a także sprawdzenie po-

\footnotetext{
${ }^{1}$ Aleksander Streubel, Państwowa Wyższa Szkoła Zawodowa, ul. Sejmowa 5a, 59-220 Legnica

2 Autor do korespondencji/corresponding author: Marek Kuran, Politechnika Wrocławska, Wybrzeże Wyspiańskiego 27, 50-371 Wrocław, tel.: (71) 3202728, fax: (71) 3280607, e-mail: marek.kuran@pwr.wroc.pl

${ }^{3}$ Rafał Subbotko, Gühring Polska, ul. Fabryczna 13, 58-100 Świdnica
} 
prawności działania w warunkach ekstremalnych. Niepoprawne działanie takiego zaworu może doprowadzić do wypadku. Istotnym elementem układu sterowania jest zawór składający się z korpusu żeliwnego (rys. 1.), wykonanego z żeliwa sferoidalnego według EN-GJS-400-15, z osadzonym w nim cylindrem stalowym (2), w którym przesuwa się stalowy tłok (3). Tłok jest podparty sprężyną (4) ze specjalnym regulatorem (5). Wzajemne skojarzenie podczas montażu korpusu (1), cylindra (2) i tłoka (3) wymaga starannego wykonania wymienionych elementów, co wynika ze skojarzenia wymiarów tłoka i otworów (rys. 2.)
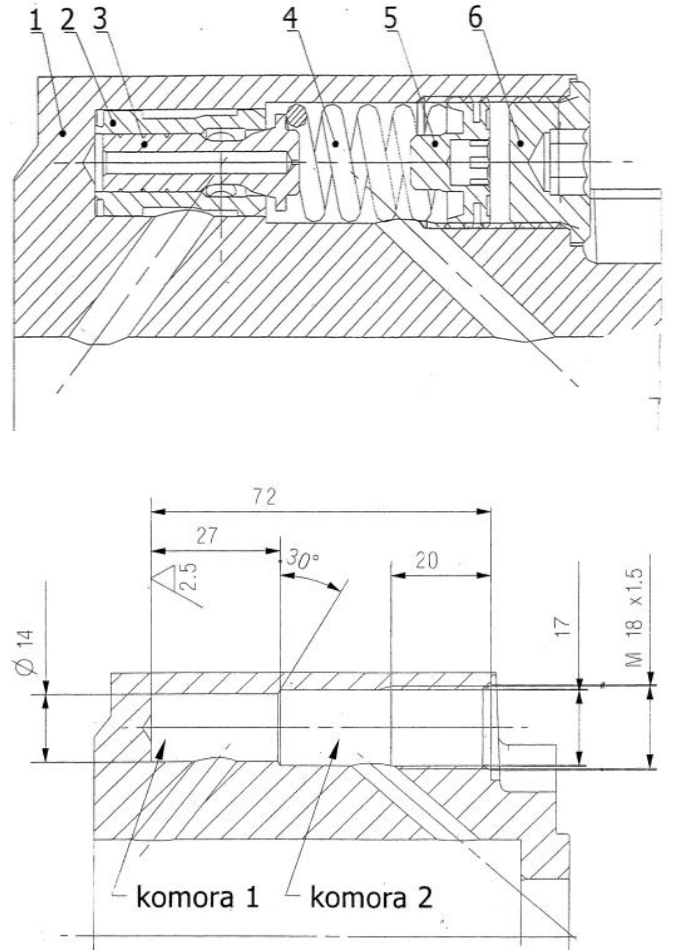

Rys. 1. Zawór i jego elementy składowe: 1 - korpus, 2 - cylinder, 3 - tłoczek, 4 - sprężyna, 5 - ustalacz, 6 - zaślepka

Fig. 1. Valve and its components: $1-$ body, 2 - cylinder, 3 - piston, 4 - spring, 5 - retainer, 6 - end cap
Rys. 2. Rysunek konstrukcyjny otworu

Fig. 2. Drawing of hole design

Proces technologiczny wykonania otworu w korpusie jest bardzo złożony, co wynika z wymagań eksploatacyjnych zaworu. Otwór w korpusie (komora 1., rys. 2.) o średnicy $14 \mathrm{~mm}$ musi posiadać dno prostopadłe do powierzchni cylindrowej, ponieważ od tego zależy poprawne osadzenie i szczelność cylindra stalowego (2, rys. 1.). Otwór końcowy (1) o średnicy $14 \mathrm{~mm}$ musi być również współosiowy z otworem komory (2) o średnicy $17 \mathrm{~mm}$. Między tymi komorami znajdują się dwie powierzchnie kształtowe, stożkowe $0,5 \times 30^{\circ}$ (dla ułatwienia montażu cylindra (2)) oraz prostopadła do powierzchni cylindrycznej komory 1. Od poprawności wymiarowej oraz kształtowej wykonania otworu zależy poprawność osadzenia cylindra (2), a w efekcie poprawność działania całego zaworu. Dotychczas otwory takie wykonywano w kilku operacjach: od wiercenia 
wiertłami o różnych średnicach, poprzez rozwiercanie i pogłębianie specjalnymi pogłębiaczami. Operacje te były czasochłonne i nie zapewniały wymaganej dokładności wymiarowej oraz chropowatości uzyskanych powierzchni otworów. Rozwój narzędzi pełnowęglikowych z kanałami doprowadzającymi chłodziwo do strefy skrawania znacznie przyspieszyło wykonanie otworów, również dzięki możliwości zwiększenia prędkości skrawania. Jedną z możliwości poprawienia jakości otworów była nowa konstrukcja stopniowych wierteł i pogłębiaczy, pozwalających na wykonanie kilku powierzchni jednym narzędziem (rys. 3. i 4.). Narzędzia zostały wykonane w całości z węglika spiekanego K20 (według oznaczenia firmy Gühring: DK460UF). Istotnym problemem w wykonaniu tego typu narzędzi jest zmiana średnicy w określonej odległości od wierzchołka oraz kątów wierzchołkowych dla każdej średnicy (rys. 3. i 4.). Znaczącą rolę w procesie wykonywania otworu odgrywają dwa kanały w narzędziu o średnicy $\varnothing 1 \mathrm{~mm}$, służące do doprowadzania chłodziwa do strefy skrawania. Pozwala to nie tylko chłodzić i smarować pracujące wiertło, ale również wspomaga proces wyprowadzania wiórów na zewnątrz wykonywanego otworu. Jest oczywiste, że takie narzędzia muszą pracować na obrabiarce wyposażonej w system umożliwiający podawanie chłodziwa przez narzędzie oraz z systemem nadzorowania procesu skrawania. Osobnym zagadnieniem jest wykonanie cylindra (2, rys. 5.).

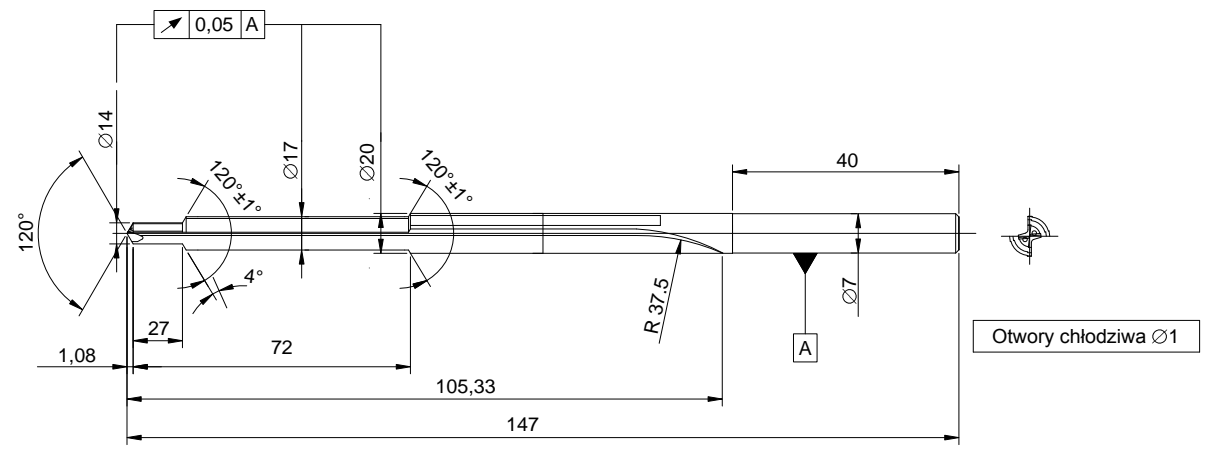

Rys. 3 Wiertło trzystopniowe $d=14 / 17 / 20 \mathrm{~mm}$ wykonane przez firmę Gühring

Fig. 3. Three-step drill $d=14 / 17 / 20 \mathrm{~mm}$ by Gühring

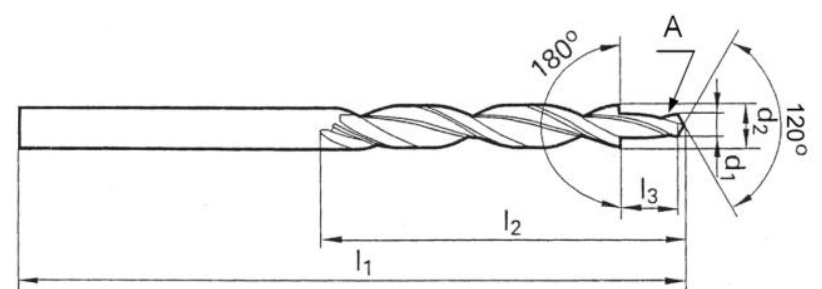

$\underline{A}$

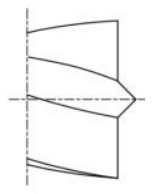

Rys. 4. Pogłębiacz

Fig. 4. Countersink 


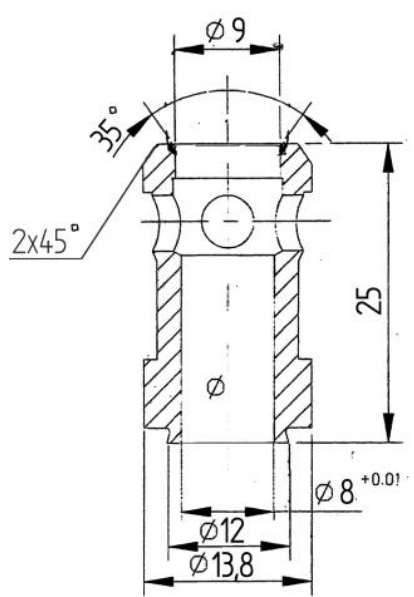

Rys. 5. Rysunek konstrukcyjny cylindra

Fig. 5. Drawing of cylinder design

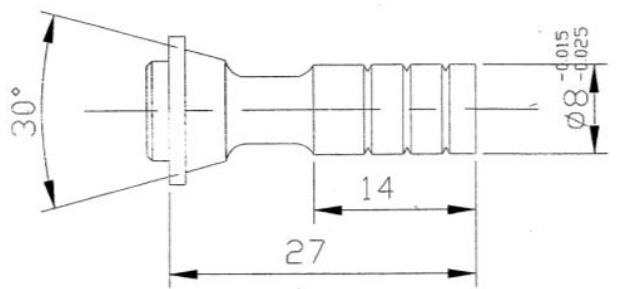

Rys. 6. Rysunek konstrukcyjny tłoczka do zaworu

Fig. 6. Drawing of valve's piston design

Problemem jest uzyskanie odpowiedniej współosiowości otworu $\varnothing 8 \mathrm{~mm}$, w którym pracuje tłoczek (rys. 6.), ze stożkiem wewnętrznym o kącie wierzchołkowym $35^{\circ}$ oraz fazą 2 x $45^{\circ}$ na średnicy zewnętrznej. Stożek wewnętrzny współpracuje ze stożkiem na tłoczku. Faza 2 x $45^{\circ}$ jest konieczna do prawidłowego zagniecenia po montażu korpusu cylindra, co wykonuje się specjalnym narzędziem. Zagniecenie to eliminuje niekontrolowane przecieki pomiędzy komorami 1. i 2. Po upewnieniu się, że tłok płynnie porusza się w cylindrze przystępuje się do montażu sprężyny (4), ustalacza (5) i korka (6).

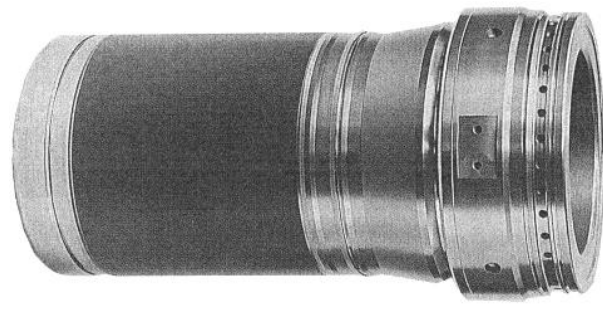

Rys. 7. Przykład tulei wielkogabarytowej silnika

Fig. 7. Example of large dimension engine's cylinder

W wielu dziedzinach gospodarki (motoryzacja, chemia, górnictwo) zastosowanie znajdują cylindry o średnicy do $600 \mathrm{~mm}$ i długościach przekraczających 
10 średnic. Ze względu na wymagania jakościowe wykonanie takiego cylindra sprowadzało się do stosowania specjalnej technologii. Klasycznym przykładem takiego elementu jest wielkogabarytowa tuleja silnika spalinowego (rys. 7.).

W motoryzacji tuleje wielkogabarytowe mają średnice $250 \div 600 \mathrm{~mm} \mathrm{i} \mathrm{dłu-}$ gość $2 \div 3$ średnic. Tuleje wykonuje się z żeliwa o specjalnych właściwościach mechanicznych: wytrzymałości na rozciaganie $\sim 350 \mathrm{MPa}$ i twardości $\sim 300 \mathrm{HB}$. Muszą one mieć także specjalną strukturę metalograficzną, zapewniającą odporność na ścieranie. Metody wykonywania takich tulei oraz warunki ich technicznego odbioru są omówione $\mathrm{w}$ dostępnej literaturze [1]. W publikacjach tych są omówione również metody montażu tłoków z pierścieniami cylindrowymi. W budownictwie i górnictwie powszechnie stosuje się cylindry hydrauliki siłowej (np. rdzenniki). Klasyczną tuleję cylindrową hydrauliki siłowej pokazano na rys. 8.

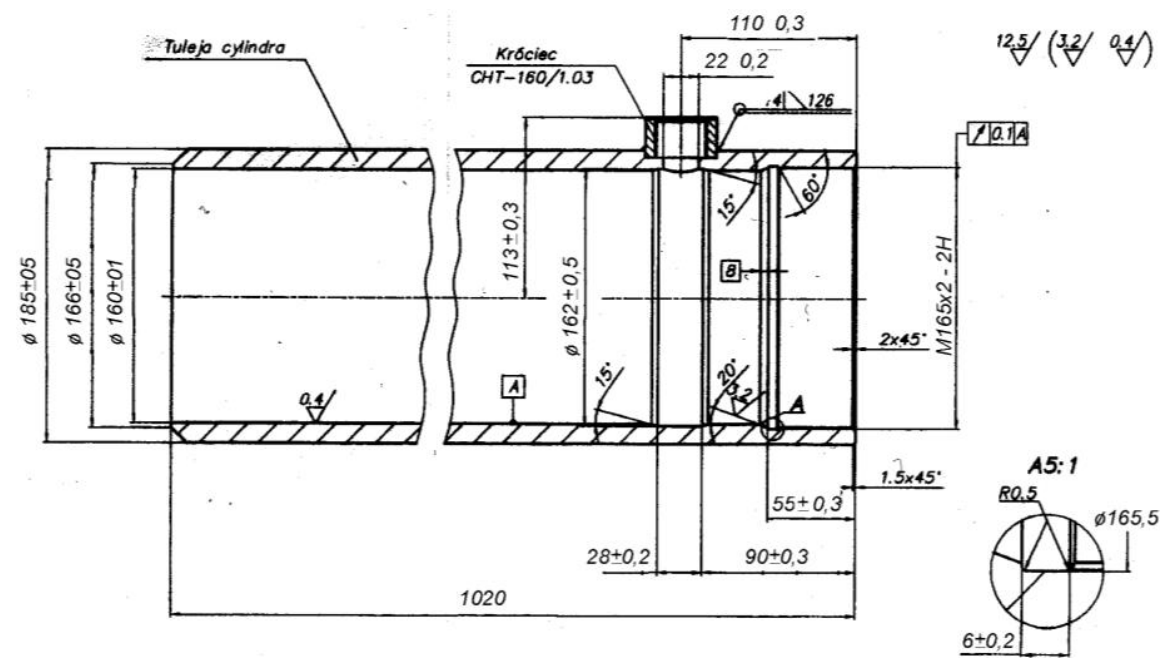

Rys. 8. Tuleja cylindrowa hydrauliki siłowej

Fig. 8. Cylinder of hydraulics actuator

Trudnością technologiczną w tym przypadku jest uzyskanie wymaganych kształtów wewnątrz cylindra, jak np. cylindryczna powierzchnia $\mathrm{z}$ fazkami pod kątem $15^{\circ}$ na głębokości 55 i $90 \mathrm{~mm}$ decydujących o równomiernym rozprowadzeniu oleju w cylindrze, dostarczanego przez króciec oraz cylindryczne kształtowe wybranie z fazą na zakończeniu gwintu na głębokości $55 \mathrm{~mm}$. Osobnym zagadnieniem jest uzyskanie odpowiedniej struktury geometrycznej powierzchni otworu, która może być płaskowierzchołkowa lub ostra (rys. 9.), o chropowatości powierzchni $R z<15 \mu \mathrm{m}$, walcowości, kołowości i liniowości poniżej $4 \mu \mathrm{m}$ (otwór wytoczony na specjalnym stanowisku musi być dodatkowo honowany). Kąt honowania, czyli przecinania się rys honowniczych, powinien zawierać się w przedziale $\pm 30^{\circ}$. Na rysunku 10a przedstawiono poprawnie wykończoną, a na 
rys. $10 \mathrm{~b}$ niepoprawnie wykończoną powierzchnię otworu. Poprawnie wykonany otwór dodatkowo obrabia się chemicznie dla uzyskania większej trwałości współpracującej ze sobą pary tłok-cylinder.
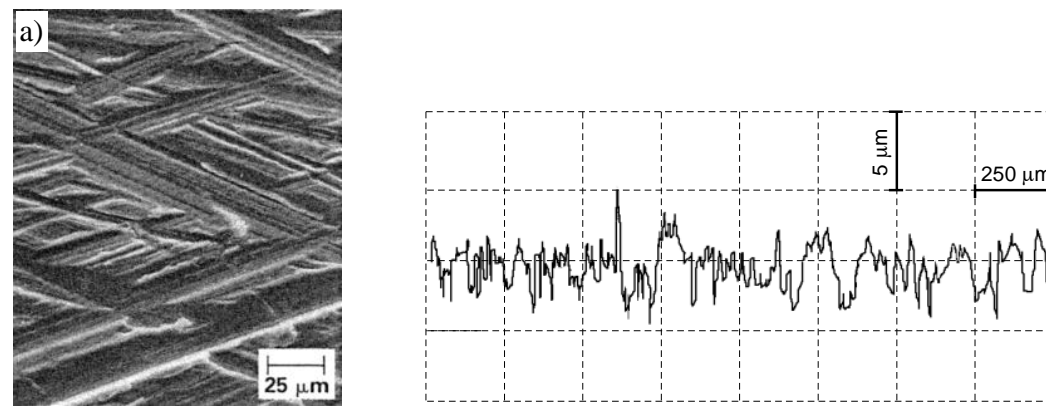

$R a=0,8 \mu \mathrm{m}$ $R z=8 \mu \mathrm{m}$
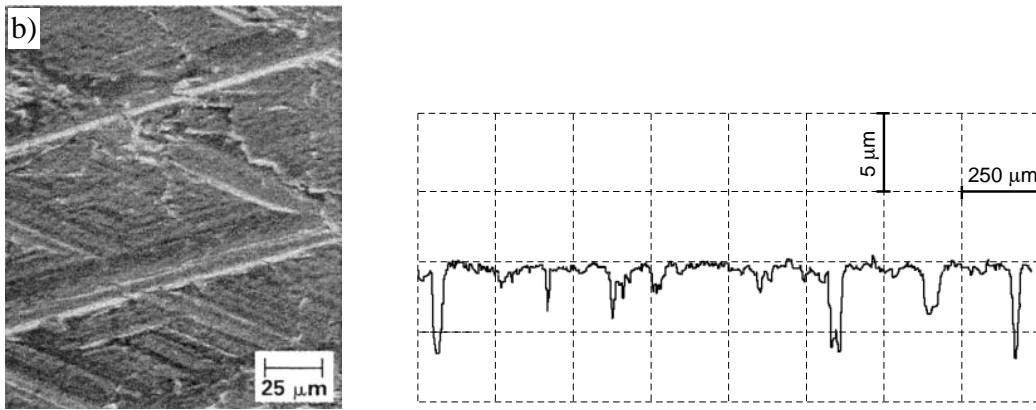

$R a=0,6 \mu \mathrm{m}$ $R z=6 \mu \mathrm{m}$

Rys. 9. Parametry honowania na ostro (a), parametry honowania na Plateau (b)

Fig. 9. Sharp honning parameters (a), plateau honing parameters (b)
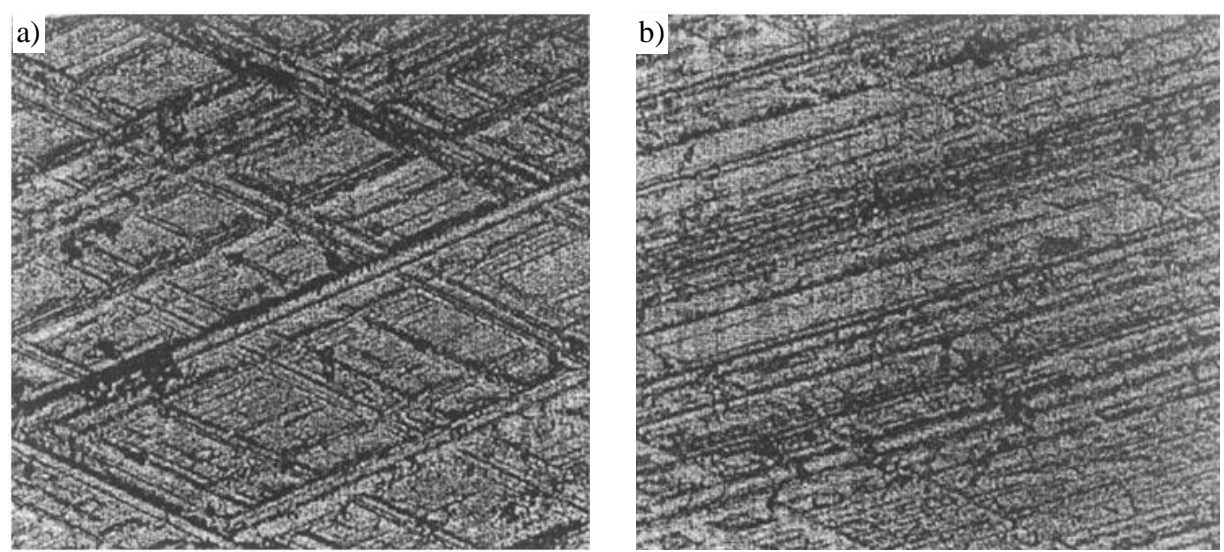

Rys. 10. Przykład prawidłowego, obukierunkowego (a) oraz nieprawidłowego, jednostronnego (b) nacięcia rys holowniczych

Fig. 10. Example of (a) the proper, two-directional and (b) inproper, one-directional honing scratches 
W przemyśle chemicznym występują dwa rodzaje cylindrów: współpracujące z tłokami lub ślimakami i przeznaczone do prowadzenia reakcji chemicznych. Drugi rodzaj cylindrów ma zazwyczaj średnicę rzędu 300 $\div 500 \mathrm{~mm}$ i długość dochodzącą do kilku metrów (rys. 11.). Wykonanie takich tulei jest niezwykle skomplikowane ze względu na gabaryty obrabianego elementu (ciężar) i materiał, z którego są wykonane (stale stopowe lub staliwa stopowe). Szczególną trudność stanowi wytoczenie otworu i tzw. zamka na czole cylindra. Operację taką prowadzi się na specjalnie wyposażonych tokarkach typu TR lub obrabiarkach do obróbki długich otworów TBT (TiefBohrTechnik). Cechą charakterystyczną tych obrabiarek jest to, że narzędzie wykonuje ruch obrotowy, a przedmiot $\mathrm{z}$ otworem lub tuleją są bazowane $\mathrm{i}$ mocowane $\mathrm{w}$ specjalnym uchwycie (rys. 12.).

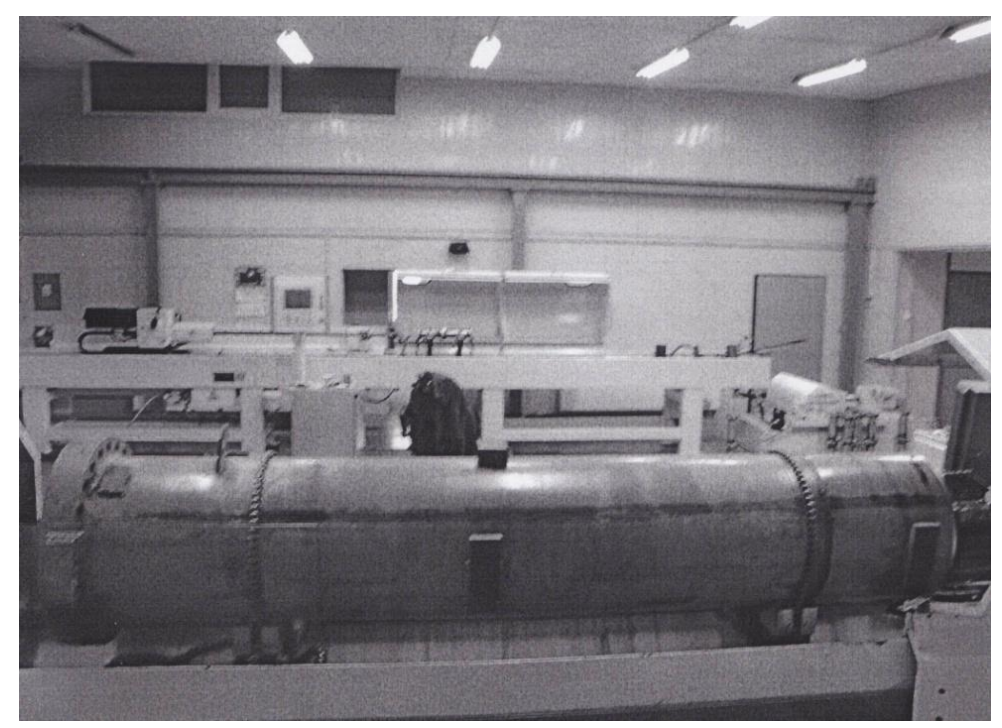

Rys. 11. Wytaczanie tulei stosowanej w przemyśle chemicznym

Fig. 11. Boring of cylinder used in chemical industry

Jest oczywiste, że proces wytaczania jest prowadzony w kilku przejściach. Szczególnie ważne jest końcowe przejście kształtujące, które musi zapewnić spełnienie w ostatniej operacji honowania stawianych otworowi wymagań. Wytoczony otwór musi mieć kształt geometryczny w dopuszczalnej tolerancji, minimalne i równomierne utwardzenie warstwy wierzchniej, właściwą strukturę warstwy wierzchniej. Na kształt geometryczny - dokładność otworu ma wpływ kilka czynników towarzyszących procesowi skrawania. Intensywność ich oddziaływania zależy od gabarytów otworu. Największy problem stanowi trwałość narzędzia, które z przedmiotem styka się na drodze dochodzącej nawet do kilku kilometrów. W efekcie styku ma miejsce starcie promienia wierzchołka ostrza, 


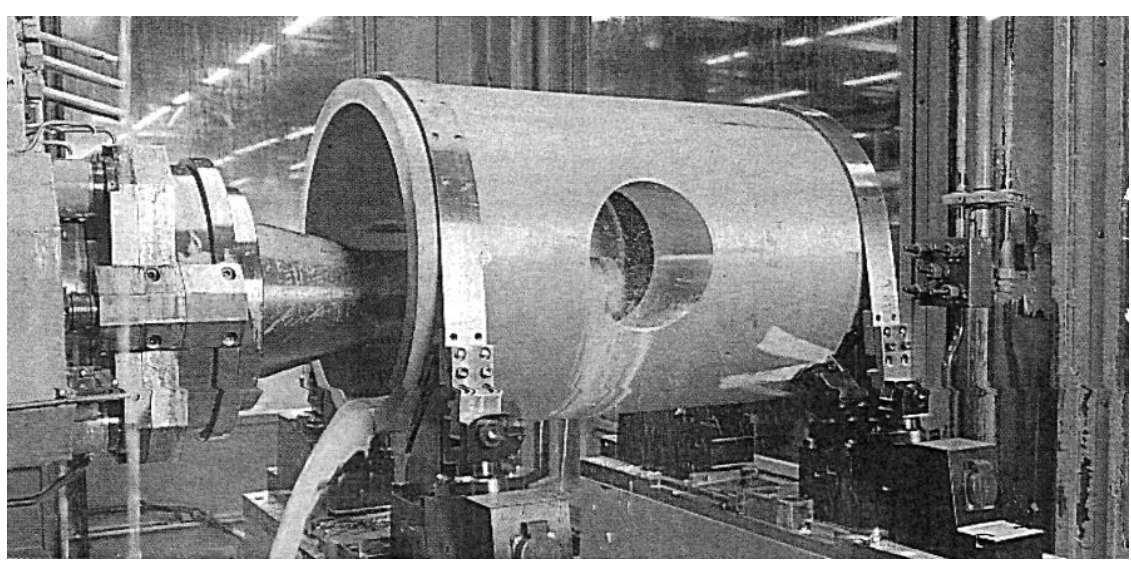

Rys. 12. Wytaczanie tulei wielkogabarytowej

Fig. 12. Boring of large dimension cylinder

co z kolei wpływa na wzrost oporów skrawania i temperaturę procesu, utwardzanie warstwy wierzchniej oraz zmianę średnicy otworu. Wymiana ostrza noża według własnych doświadczeń autorów nie może mieć miejsca. Duże utrudnienie stanowią opory skrawania towarzyszące procesowi, mimo że dzięki doborowi optymalnych dla danego materiału parametrów skrawania i stereometrii ostrza mają minimalną wartość rzędu $\mathrm{F}_{\mathrm{z}} \sim 500 \mathrm{~N}$ i $\mathrm{F}_{\mathrm{y}} \sim 300 \mathrm{~N}$. Mając na uwadze ich umiejscowienie względem osi otworu mogą one mieć wpływ na efekt obróbki. Kolejny problem to uzyskanie stałego utwardzenia warstwy wierzchniej otworu, co jest szczególnie ważne w wytwarzaniu otworów w stalach ferrytycznych i austenitycznych. Według badań autorów utwardzenie warstwy wierzchniej może wzrosnąć nawet do $50 \%$, a głębokość zmian w niektórych materiałach - do 0,5 mm. Wielkościami tymi można $\mathrm{w}$ pewnym zakresie sterować przez zmianę promienia i kąta natarcia noża oraz zmiany parametrów skrawania. Czynności te mają jednak wpływ na trwałość ostrza; możliwości zmian są więc ograniczone.

Obróbka wykończająca otworu najczęściej sprowadza się do jego honowania lub docierania [2]. Honowanie nie może uszkodzić powierzchni czół wykonanych podczas wytaczania oraz musi zapewnić zachowanie prostopadłości powierzchni otworu i czoła. Do obróbki tulei cylindrowych małych średnic stosuje się honownice dawnej firmy WMW (NRD) oraz nowszej konstrukcji firm Kadia, Sunnen, Nagel. Te nowoczesne obrabiarki mają możliwość honowania głowicami dwustopniowymi z pomiarem aktywnym, z możliwością programowania wielkości nacisków jednostkowych osełki na powierzchnię, zmiany kierunku obrotu wrzeciona, automatycznego dostosowania punktów nawrotu głowicy honowniczej celem poprawienia istniejących błędów kształtu otworu. Tuleje wielkogabarytowe honuje się najczęściej na obrabiarkach firmy Gehring 
i Sunnen pracujących w układzie poziomym. Przykład honowania tulei wielkogabarytowej przedstawia rys. 13.

Rys. 13. Honowanie tulei wielkogabarytowej

Fig. 13. Honing of large dimension cylinder

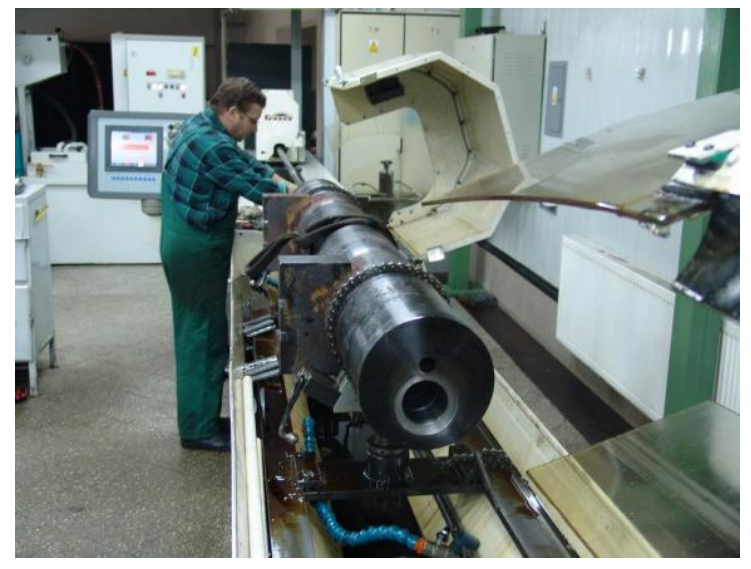

Do honowania tulei cylindrowych używa się narzędzi: osełek z nasypem diamentowym, borazonowym, osełek ceramicznych, a do docierania - docieraków żeliwnych i luźnego ścierniwa [3-5]. Osełki diamentowe są stosowane niemal wyłącznie w operacji honowania wstępnego, mającej na celu przygotowanie otworu pod honowanie końcowe. Najczęściej do tej operacji używa się osełek diamentowych o ziarnistości D-356 o spoiwie brązowym i koncentracji 75\%.

Wykonanie honowania płaskowierzchołkowego Plateau wymaga stosowania osełek ceramicznych o różnych ziarnistościach: gruboziarnistych do nacinania głębokich rys podstawowych i drobnoziarnistych do ścięcia wierzchołków nierówności, z pozostawieniem rys wgłębnych. Do nacinania rys podstawowych są stosowane narzędzia o ziarnistości od 100 do 150 (najczęściej 120), miękkim spoiwie, otwartej, porowatej strukturze, nasączane siarka, oraz drobnoziarnistych do ścięcia wierzchołków o ziarnistości od 320 do 500, wyjątkowo do 1000. Bardzo istotne $\mathrm{w}$ honowaniu długich otworów jest właściwe połączenie głowicy $\mathrm{z}$ wrzecionem obrabiarki. Do tego celu służą specjalne żerdzie z przegubami na obu końcach (rys. 14.) oraz urządzeniem do regulacji nacisków osełek na obrabianą powierzchnię (rys. 15.).

Ze względu na charakter pracy, zmienne cykliczne obciążenie wzdłużne, jak i znaczny moment skręcający, żerdzie mają specjalną konstrukcję. Żerdź jest wykonana z cienkościennej rury stalowej lub grubościennej rury ze stopów aluminium. Każda obrabiarka jest wyposażona w typoszereg żerdzi i instrukcję ich stosowania. Wadliwy dobór powoduje pogorszenie jakości obrabianej powierzchni i może spowodować uszkodzenie głowicy. Istotnym zagadnieniem jest temperatura procesu skrawania. $Z$ badań prowadzonych przez autorów w firmie JURGAL wynika, że wzrost temperatury przedmiotu o kilkanaście stopni utrudnia uzyskanie wymaganej dokładności. 


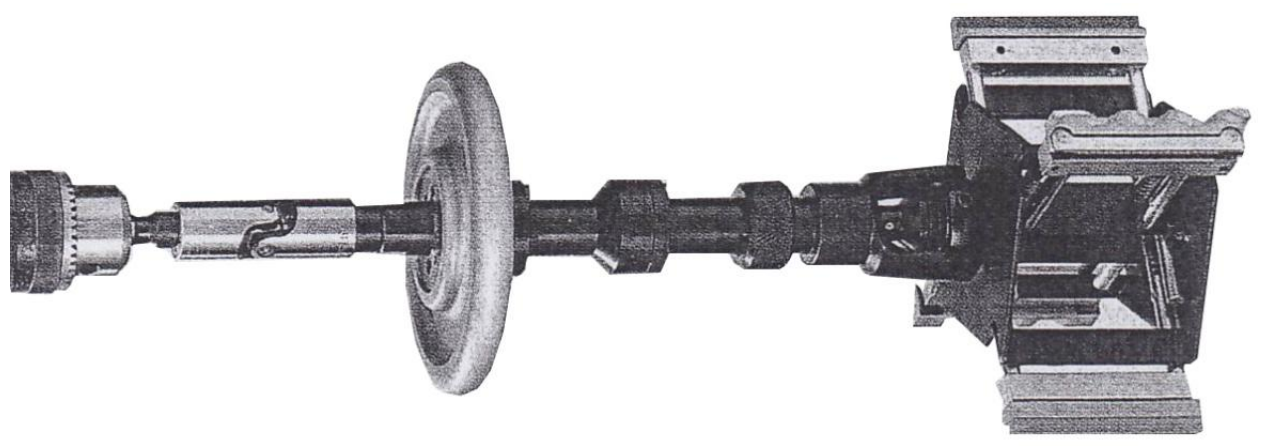

Rys. 14. Żerdź do mocowania głowicy

Fig. 14. Perch for head mount

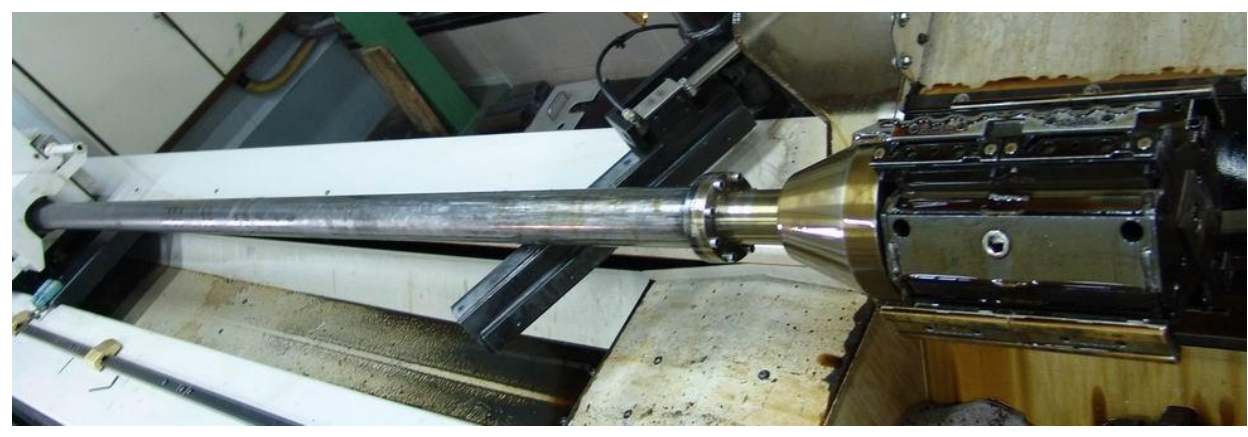

Rys. 15. Żerdź z przegubami do mocowania głowicy honowniczej na wrzecionie obrabiarki

Fig. 15. Perch with cardings for head mount on the tool machine

Płyny chłodząco-smarujące mają za zadanie wypłukiwanie startych cząsteczek materiału obrabianego, wykruszonych i zużytych ziaren ściernych z osełki, smarowanie podczas procesu oraz bardzo często intensywne chłodzenie honowanego przedmiotu. Obecnie każdy producent obrabiarek do honowania preferuje oleje lub inne płyny od określonego producenta, które bardzo często różnią się tylko ceną. Podstawowy olej honownicy ma lepkość rzędu $6,4 \mathrm{~mm}^{2} / \mathrm{s}$ przy $20^{\circ} \mathrm{C}$ oraz gęstość $0,82 \mathrm{~g} / \mathrm{cm}^{3}$ przy $15^{\circ} \mathrm{C}$. Ilość podawanego płynu zależy od kilku czynników, tj. gatunku honowanego materiału, narzędzia, kinematyki honowania, wielkości przedmiotu. Zalecana przez producentów ilość to około $80 \div 100$ 1/min przy ciśnieniu $0,15 \mathrm{MPa}$. Dla poziomego układu honowania wartości te muszą być często wyższe. W przypadku elementów dla chemii (materiały kwasoodporne), ze względu na silne nagrzewanie się przedmiotu w procesie obróbki, wydajności chłodzenia muszą być kilkakrotnie wyższe. Osobne zagadnienie stanowi filtracja płynu chłodząco-smarującego. W starszych rozwiązaniach maszyn stosowano głównie magnetyczne separatory. Obecnie obrabiarka 
jest wyposażona w specjalny agregat stabilizujący temperaturę, jak i filtrujący płyn.

\section{Podsumowanie}

Zawór, pomimo prostej budowy, nastręcza problemów podczas jego wykonywania oraz montażu. Pozornie błahe powierzchnie, jak np. prostopadłe do osi otworu dno czy fazy, decydują de facto o szczelności połączeń, a więc o poprawności pracy gotowego wyrobu. Osadzenie stalowego cylindra w żeliwnym korpusie i uszczelnienie go przez dogniecenie stanowi interesujące rozwiązanie tego zagadnienia. W procesie wytwarzania zaworu konieczne jest zastosowanie nowoczesnych rozwiązań konstrukcyjnych narzędzi, co pozwala na organicznie liczby braków. Tuleje cylindrowe hydrauliki siłowej należą do produktów wymagających specyficznego procesu technologicznego. Należy zapewnić dobrą współprace pomiędzy tłokiem i cylindrem, trwałość, a jednocześnie umożliwić poprawny i łatwy montaż współpracujących części. Istotną rolę odgrywa stożek przejściowy pomiędzy częścią roboczą (cylindryczną) a częścią gwintowaną, który musi być współosiowy. Jego zadanie to ułatwienie montażu tłoka w cylindrze. Elementy wykonywane dla przemysłu chemicznego mają do spełnienia różne zadania. Wymaga to stosowania każdorazowo indywidualnych metod obróbki, często odbiegających od powszechnie stosowanych. Jednak nie każdy zakład produkcyjny jest w stanie je spełnić.

\section{Literatura}

1. Kleparski B.: Honowanie żeliwnych tulei cylindrowych Mahle Krotoszyn. Referat przygotowany na 66 posiedzenie Sekcji Podstaw Technologii PAN Krotoszyn 2001. Wydawnictwo Politechniki Wrocławskiej, Wrocław 2001.

2. Streubel A., Kuran M., Uchman M.: Wykonanie i regeneracja otworu w cylindrze hydrauliki siłowej. Obróbka skrawaniem, t. 2. Innowacje, J. Stós (red.). Instytut Zaawansowanych Technologii Wytwarzania, Kraków 2008.

3. Sunnen. Materiały informacyjne firmy.

4. Gehring. Materiały informacyjne firmy.

5. Streubel A., Kuran M., Uchman M.: Kształtowanie powierzchni wewnętrznej w wielkogabarytowych tulejach. Wydawnictwo Uniwersytetu Technologiczno-Przyrodniczego, Bydgoszcz 2009.

\section{MACHINING OF CYLINDRICAL HOLES TECHNOLOGICAL PROLEMS IN DEPENDENCE OF THEIR APPLICATION}

\section{Abstract}

The paper discusses the problems of the preparation of cylindrical holes for montage in objects used in control systems, hydraulics and intended to chemical reactions. Sometimes producing the simple part presents difficulties in the manufacturing and assembling. Seemingly trivial 
surfaces as bottom perpendicular to the axis of the hole or chamfers decide de facto about leaktightness of connections and therefore about the correct operation of the final product. Hydraulic components are products that require a specific manufacturing process. For example, in the manufacture of the valve it is necessary to use the modern design solutions of tools, which allow to limit the number of faulty products. Parts manufactured for the chemical industry have to fulfill different tasks. This requires the application of individual treatment methods each time, often different from those commonly used, and not every production plant is able to fulfill them. The aim of this paper is to draw attention to the technological requirements that must be fulfilled in order to manufactured elements operate correctly and as expected.

Keywords: machining, cylindrical holes, coaxiality

DOI: $10.7862 / \mathrm{rm} .2013 .7$

Otrzymano/received: 25.02 .2013

Zaakceptowano/accepted: 22.04.2013 